\title{
How prior knowledge, learning, teaching and assessment affect students' achievements in Mathematics
}

La influencia de los conocimientos previos, el aprendizaje, la enseñanza y la evaluación en la adquisición de conocimientos del alumno en matemáticas

La influència dels coneixements previs, l'aprenentatge, l'ensenyament i l'avaluació en l'adquisició de coneixements de l'alumne en matemàtiques

\author{
Nazmi Xhomara*i] \\ Department of Mathematics and Statistics, Luarasi University, Tirana, Albania \\ ${ }^{*}$ Corresponding author: nazmi.xhomara@luarasi-univ.edu.al (Nazmi Xhomara)
}

Received: 09/11/2019 | Accepted: 06/22/2020 | Published: 12/24/2020

Citation: Xhomara, N. (2020). How prior knowledge, learning, teaching and assessment affect students' achievements in Mathematics. Research in Education and Learning Innovation Archives, 25,68-91. 10.7203/realia.25.15780

Copyright: The Authors. Open Access: This article is distributed under the terms of the Creative Commons Attribution-NoDerivatives 4.0 International licence (CC BY-ND 4.0)

\begin{abstract}
In this study we investigate how prior knowledge, the comprehensive learning approach, problem-based teaching and assessment influence students' basic-learning skills in Mathematics at the university level. To do so, we employed a quasi-experimental research design and a structured questionnaire. Two experimental groups and two control groups of students were involved. We found a negligible correlation between prior knowledge and basic-learning skills but a positive correlation between prior knowledge and the comprehensive learning approach. On the other hand, we found practically no correlation between prior knowledge and assessment. We also found that problem-based teaching correlated positively and that the traditional approach correlated negatively with prior knowledge. Moreover, prior knowledge, problem-based teaching, the comprehensive learning approach and assessment explained $50 \%$ of the variance in the levels of basic-learning skills.
\end{abstract}

KEYWORDS: prior knowledge; comprehensive learning approach; problem-based-instruction; assessment impact; student's basic knowledge conceived in mathematics

RESUMEN: El objeto de este estudio es investigar la influencia del conocimiento previo del alumnado, el enfoque de aprendizaje integral, la enseñanza basada en problemas y el impacto de la evaluación en el aprendizaje básico del estudiante de matemáticas a nivel universitario. La investigación plantea un diseño de investigación cuasi experimental y un cuestionario estructurado. En él participaron dos grupos experimentales y dos grupos de control. Los resultados muestran que existe una correlación no significativa entre el conocimiento previo y la habilidad de aprendizaje básico; también plantea que un enfoque de aprendizaje integral se correlaciona positivamente con el conocimiento previo, mientras que con la evaluación casi no existe correlación, si bien existe una correlación positiva con la enseñanza basada en problemas. El enfoque tradicional se correlaciona negativamente con el conocimiento previo. Otros resultados que se obtienen es que el conocimiento previo, la enseñanza basada en problemas, el enfoque de aprendizaje integral y el impacto de la evaluación explican el $50 \%$ de la variación en los niveles de habilidades de aprendizaje básico.

PALABRAS CLAVE: conocimientos previos; enfoque de aprendizaje integral; aprendizaje basado en problemas; evaluación de impacto; conocimientos previos del estudiante en matemáticas 
RESUM: El propòsit d'aquest estudi és investigar la influència del coneixement previ de l'alumnat, l'enfocament d'aprenentatge integral, l'ensenyament basat en problemes i l'impacte de l'avaluació en l'aprenentatge bàsic de l'estudiant de matemàtiques a nivell universitari. La investigació planteja un disseny quasiexperimental i un qüestionari estructurat. Hi van participar dos grups experimentals i dos grups de control. Els resultats mostren que hi ha una correlació no significativa entre el coneixement previ i l'habilitat d'aprenentatge bàsic. L'estudi també va revelar que un enfocament d'aprenentatge integral es correlaciona positivament amb el coneixement previ, mentre que amb l'avaluació gairebé no hi ha correlació. D'altra banda, s'observa que hi ha correlació positiva amb l'ensenyament basat en problemes. L'enfocament tradicional es correlaciona negativament amb el coneixement previ. La investigació també planteja que el coneixement previ, l'ensenyament basat en problemes, l'enfocament d'aprenentatge integral i l'impacte de l'avaluació expliquen el 50\% de la variació en els nivells d'habilitats d'aprenentatge bàsic.

PARAULES CLAU: conexements previs; enfocament d'aprenentatge integral; aprenentatge basat en problemes; avaluació d'impacte; coneixements previs de l'alumnat en matemàtiques

\section{Practitioner Notes}

\section{What is already known about the topic}

- Mathematics proficiency has always been a challenge for lecturers and students at university. Many researchers have investigated the factors related to students' achievements in mathematics, such as mathematics preferences, teachers' knowledge and teacher's behavior, as well as students' thinking and learning, and cognitive complexity.

\section{What this paper adds}

- The researcher examined and revealed that a comprehensive learning approach correlates positively with knowledge conceived, as well as half of the variance of basic-learning skill levels is explained by prior knowledge, problem-based teaching, comprehensive learning approach, and assessment impact. The researcher also found that problem- based teaching is making a significant positive contribution, meanwhile, the traditional approach is making a significant but negative contribution to the prediction of basic-learning skill.

\section{Implications of this research and / or paper}

- While students' achievements in mathematics has proven to be the most challenging experience for students, as well as the lecturers, mathematics departments might pre-test prior knowledge of students to strengthen their work to increase their academic success in mathematics, as well as might promote the comprehensive learning approach, and. problem-based teaching. There is a need to investigate the influence of other variables on basic-learning skill in mathematics.

\section{INTRODUCTION}

The prior mathematics knowledge, comprehension learning approach, as well as problem-based teaching used by teacher and assessment impact, are supposed to be the important variables that influence knowledge conceived in mathematics. The main aim of the study was to investigate the impact of prior knowledge, comprehensive learning approach, problem-based teaching and assessment impact on student's basic-learning skill in mathematics. Learning is to be student-initiated and that ample time for self-study should be available (Evensen \& Hmelo-Silver, 2000; Hmelo-Silver, 2004; Schmidt, 1983, 1993). Experiential learning should be triggered by a problem, understood as an unclear situation or phenomenon in need of an explanation (Dewey, 1934). Problem-based instruction has been deemed one of the most innovative pedagogies to better benefit student learning (Moallem, Hung, \& Dabbagh, 2019), and includes a process of inquiry, learning to learn, or cognitive constructivist approach (Schmidt, Molen, Wilkel, \& Wijnen, 2009). Therefore, problem-based instruction including the use of problems as the starting point for learning, students 
collaborating in small groups, and flexible guidance of a tutor (Schmidt, Rotgans, \& Yew, 2019). Experiential learning, problem-based teaching, as well as other approaches are some of the characteristics of teaching and learning in mathematics. Solbrekke and Helstad (2016) pointed out that teaching in higher education encompasses engaging students in their formation; meanwhile, Hourigan and O'Donoghue (2007) indicated that the ability of students to tertiary level mathematics education lies in the nature of entrants' pre-tertiary mathematical experiences. Kajander and Lovric (2005) pointed out that the transition between secondary and tertiary education in mathematics is a complex phenomenon; meanwhile, Harwell et al. (2009) provide evidence that curricula do not prepare students to enroll in difficult university mathematics courses. Edwards, Sandoval, and McNamara (2015) revealed that more than $60 \%$ of students are required to complete one mathematics class before enrolling in college. On average across OECD countries, $28 \%$ of students are able to solve only straightforward collaborative mathematics problems, and $8 \%$ of students are top performers, meaning that they can maintain an awareness of group dynamics, ensure team members act in accordance with their agreed-upon roles, and resolve disagreements and conflicts while identifying efficient pathways and monitoring progress towards a solution (OECD, 2019). The conceptual definitions of the main variables selected to use in the study are explained as follows. Prior knowledge means grade in math in the previous academic year. Comprehensive learning approach indicates including information from different sources as class teaching, reading material, practical, etc. by students. Problem-based teaching stands for supporting the students to learn a lot in every lesson by the lecturer. Assessment impact means trying to learn from mistakes and study better next time if the students don't do well in an exam. And finally, basic-learning skill signifies to be able to learn the basic concepts taught in the math course subject.

\section{THEORETICAL FRAMEWORK AND LITERATURE REVIEW}

The fundamental factors in the educative process are an immature, undeveloped being; and certain social aims, meanings, values incarnate in the matured experience of the adult. The educative process is the due interaction of these forces. Abandon the notion of subject- matter as something fixed and ready-made in itself, outside due child's experience; cease thinking of the child's experience as also something hard and fast; see it as something fluent, embryonic, vital; and we realize that the child and the curriculum are simply two limits which define a single process. The present standpoint of the child and the facts and truths of studies define instruction (Dewey, 1902, 182-189). Constructivism theory must be used as a basis of the theoretical framework. Constructivism is an instruction paradigm posits that learning is an active, constructive process, and where the learner is an information constructor, and actively construct or create their subjective representations of objective reality (David, 2015). New information is linked to prior knowledge, thus mental representations are subjective, and students would engage in real-world, practical workshops in which they would demonstrate their knowledge through creativity and collaboration (Creighton \& Dewey, 1916). Each student has a base level of knowledge, but they can increase it by practicing what they know well and adding onto it, and the social interaction between the student, teacher and other students reinforces their increase of knowledge (Vygotsky, 1980). In this context constructivism is served as a fundamental basis of problem-based teaching, as well as comprehensive learning approach and learning skills and competencies.

\subsection{Conceptual framework}

Constructivism is grounded in the concept that learners construct their understanding through experiences and interpretations (Dewey, 1934). This construction of knowl- 
edge comes initially from the prior knowledge, experiences, attitudes, and interests that individuals bring to learning that transpires when individuals apply these factors to new experiences and situations (Howe \& Berv, 2000). According to Howe and Berv (2000), constructivist paradigm requires active participation in the classroom, where learners participate in generating understanding (Brooks \& Brooks, 1993). The framework for the study, as shown in Figure 1, is based on constructivism, and was also developed from an extensive review of existing evidence about the relationship between main variables. The review began with a search for relevant empirical research through ERIC, EBSCO, and Sage, using the keywords prior knowledge, comprehensive learning approach, problem-based teaching, assessment impact, and student's basiclearning skill. The results of the study were interpreted in terms of constructivism theory, and research conducted in the field.

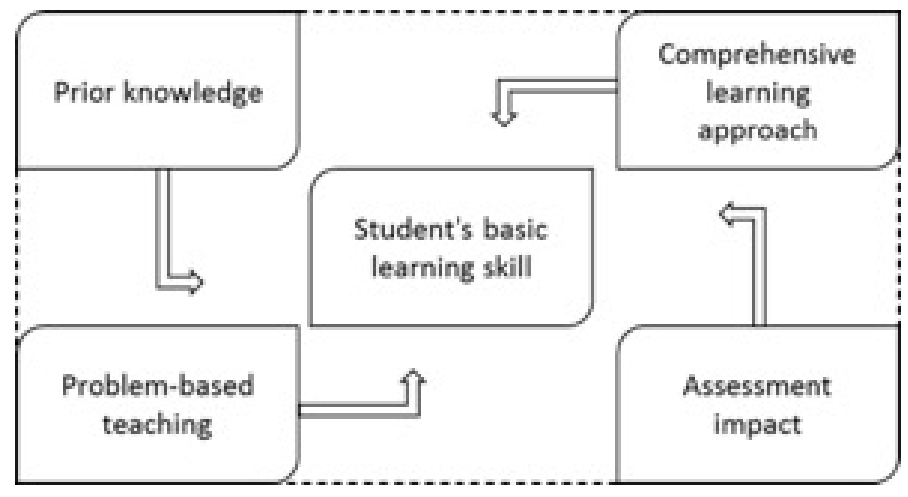

Figure 1. Conceptual framework.

\subsection{Literature review}

\subsubsection{Relationship between prior mathematical knowledge and basic-learning skill}

Prior mathematical knowledge in secondary education is thought to be one of the most important premises to obtain good grades in mathematics in the university studies. Many authors have done a lot of research to investigate the association between prior knowledge in mathematics and basic-learning skill in university studies.

Prior knowledge had a positive influence on new learning (Lin \& Liou, 2019; Reinholz \& Gillingham, 2017). The high preference for mathematics have a much greater influence on the process of acquiring knowledge in mathematics (Lambić \& Lipkovski, 2012; Mutodi \& Ngirande, 2014). James, Montelle, and Williams (2008) found that the secondary school qualifications in mathematics influence their results in the core first-year mathematics, meanwhile Kizito, Munyakazi, and Basuayi (2016) found that students' perceptions of their workload emerged as the factor having the greatest impact on student's performance, and Richardson, Abraham, and Bond (2012) revealed that the academic self-efficacy, grade goal, and effort regulation generated medium-sized correlations with GPA. The higher levels of mathematical knowledge (H. C. Hill, Schilling, \& Ball, 2004; Schlomer, 2017) showed a greater focus on student mathematical thinking, meanwhile, limited mathematics thinking impact a smooth transition into mathematics programs (Hourigan \& Leavy, 2017). Flitcroft and Woods (2018) revealed that teacher behaviors to students' academic performance have both positive and negative impacts, according to their positive or negative attitude, and King and Cattlin (2015) found that there are significant negative impacts associated with students' pass rates with large numbers of students enrolling in degrees. Hence, there is evidence of positive relationship between prior knowledge, 
mathematics preferences, qualification, workload, higher levels of mathematical knowledge, as well as teacher behaviors and mathematics learning. Fernández and Figueiras (2014) found that teachers' knowledge impacts the continuity of mathematics, but Hilby, Stripling, and Stephens (2014) revealed that there is no relationship between mathematics ability of teachers. Teachers applying metacognitive skills in assisting their learners, and academic service-learning experience influence a shift away toward self-efficacy for teaching by the students (Hollingsworth \& Knight-McKenna, 2018; Tachie \& Molepo, 2019). Remillard (2005) indicated that use of mathematics curriculum materials is an increasingly widespread practice to regulate mathematics teaching, and Krain (2016) confirm that case-based materials led students to gain a better understanding of theoretical concepts. Steele, Johnson, Otten, Herbel-Eisenmann, and Carver (2015) found that student thinking influence mathematics learning, meanwhile deepened teachers' knowledge influence mathematical knowledge for students (Kaur, 2017), and colleagues' critical review provided progress of mathematics teachers (Kortjass, 2019). McLeskey and Waldron (2004) indicated that knowledge-for-practice, knowledge-in-practice, and knowledgeof practice of teacher learning (Cochran-Smith \& Lytle, 1999) influence academic progress of students, and Baumert et al. (2017a) revealed a substantial positive effect of pedagogical content knowledge on students' learning gains. Thus, it is evidenced that teachers' knowledge, meta-cognitive skills, curriculum materials student thinking, colleagues' critical review, as well as pedagogical content knowledge impact students' learning in mathematics. In conclusion, the investigation of the relationship between mathematical knowledge and basic-learning skill, as resulted in previous research, is important. Therefore, based on the above literature review it is hypothesized that:

$H$ \# 1: The higher mathematical knowledge scores are associated with higher basiclearning skill scores

\subsubsection{Relationship between comprehensive learning approach and basic-learning skill}

The comprehensive learning approach is assumed to be one of the important variables that impact basic-learning skill in mathematics at the university. A lot of research is carried out to investigate the association between comprehensive learning approach in mathematics and basic-learning skill at university. Karagiannopoulou and Christodoulides (2005) found that the learning is a stronger predictor of academic achievement, and Jenkins (2017) indicated that problem-based learning impacts positively the students' proficient level in mathematics. Wyse and Soneral (2018) revealed that the cognitive complexity is a contributor of the learning process, and Gilstrap (2019) reports a strong correlation between the standards for learners and the approaches to learning. Crawford and Wang (2015) revealed an increasingly significant performance by prior academic performance, and Johnson, Johnson, and Johnson (2017) found that comprehensive learning impact student achievements. Yildirim (2017) pointed out that flipped classroom increases the learning, and Rimbey (2013) revealed significant differences in classroom practice as a result of the treatment using the learning mathematics for teaching. Thus, it is evidenced that problem-based learning, cognitive complexity, standards for learners, prior academic performance, comprehensive learning, flipped classroom correlate positively with basic-learning skill. Tsouccas and Meletiou-Mavrotheris (2019) indicated a positive impact of utilizing mobile apps as an instructional tool, and Holmes and Hwang (2016) showed that the students benefited greatly from the problem- based learning in mathematics. White and Nitkin (2014) demonstrate the positive impact of the program on students learning, meanwhile Alkhateeb (2003) found that surface learning and deep learning approach accounting for $34.6 \%$ of variance to learning mathematics. Barakat (2005) showed that differences in the teaching methods yielded no statistically significant differences in 
skills, but Schaub and Baker (1991) revealed that instructional methods yield higher mean classroom knowledge. Kogan and Laursen (2014) pointed out that the impact of inquiry-based learning on students' grades is sizable and persistent. Hence, there is evidence that mobile apps, the program, deep learning approach, instructional methods, and inquiry-based learning influence basic-learning skill. In conclusion, the investigation of the relationship between a comprehensive learning approach and basiclearning skill, as resulted by previous research, indicates the scientific and practical importance. Therefore, based on the above research it is hypothesized that:

$H$ \# 2: The higher comprehensive learning approach scores are associated with higher basic-learning skill scores

\subsubsection{Relationship between problem-based teaching and basic-learning skill}

Problem-based teaching used by math teachers is supposed to be one of the most important variables that impact basic-learning skill in mathematics. A lot of research has been done to investigate the association between problem-based teaching in mathematics and basic-learning skill at university.

Collaborative problem-solving performance is positively related to performance in the core PISA subjects (science, reading and mathematics), but the relationship is weaker than that observed among those other domains (OECD, 2019). The mathematics teaching predicted achievement, quality of the learning, and learning experience (Giles, Byrd, \& Bendolph, 2016; Huntley, 2013; Karagiannopoulou \& Christodoulides, 2005; Serra, Bikfalvi, Masó, Carrasco, \& Garcia, 2017). From the other point of view, Toetenel and Rienties (2016) found no positive correlation between learning design and student outcomes. Virtual manipulatives displayed considerable growth in students' learning, and better performance in mathematics (Demir, 2018; Lee \& Chen, 2014); but Wilder and Berry (2016) indicated that the traditional approach to instruction was equally effective in improving student mathematics knowledge. Students who received e- problem-based learning instruction Baele (2017) self-reported significantly greater engagement than those who received traditional instruction, and face-to-face courses Derr (2017). Therefore, as above work evidenced, the collaborative problem-solving performance, mathematics teaching, virtual manipulatives, e- problem-based learning instruction correlate positively with basic-learning skill.

Maciejewski (2016) pointed out that how a student conceives the nature of a subject affects their learning outcome, and Kelly (2002) found that an equitable classroom climate in mathematics influence students' formation with knowledge. Teachers' mathematical knowledge, a computerized instructional management system, and simulated teaching environment explained significant gains in math achievement (C. H. Hill, Blazar, \& Lynch, 2015; H. C. Hill et al., 2004; Ma et al., 2016; Ysseldyke et al., 2003). Kearns and Fuchs (2018) found that cognitively focused instruction accelerated low-achieving students' academic progress, but Chung (2004) revealed that students from both constructivist and traditionalist approach improved their skills. Burns (2005) indicated that solving mathematics problems often requires searching for new approaches, and there is a significant improvement in mathematics' achievement influenced by the learning style approach (Al-Balhan \& Soliman, 2019; Burns, 2005). Hence, it is evidenced the positive association between conceives the nature of a subject, teachers' mathematical knowledge, computerized instructional management system, simulated teaching environment, cognitively focused instruction, and basic-learning skill. In conclusion, the investigation of the relationship between problem-based teaching and basic-learning skill, as resulted in previous research, is important. Therefore, based on the previous research it is hypothesized that: 
H \# 3: The higher problem-based teaching scores are associated with higher basiclearning skill scores

\subsubsection{Relationship between assessment impact and basic-learning skill}

Knowledge assessment of students is one of the important variables that are related to basic-learning skill in mathematics. A lot of research is carried out to investigate the association between assessment impact in mathematics and basic-learning skill in the university studies.

Assessment methods and matriculation examination score were the predictors of students' progress (Karagiannopoulou \& Christodoulides, 2005; Kizito et al., 2016). Duzhin and Gustafsson (2018) found that online homework with immediate feedback was found to be even more effective than clickers, as well as Abushammala (2019) indicates that the use of multiple in-class activities and digital technology are important to enhance students' performance. Lees and Anderson (2015) pointed out that formative assessment may improve student performance, and Brosvic, Dihoff, Epstein, and Cook (2006) revealed that feedback facilitates the acquisition of mathematics knowledge. Mathematics teachers' judgments and information literacy assessment were highly predictive of students' performance Chen (2006); Pinto and Fernández-Pascual (2017). Thus, assessment methods, matriculation examination score, online homework with immediate feedback, multiple in-class activities, digital technology, formative assessment, mathematics teachers' judgments, as well as information literacy assessment are associated with basic-learning skill.

Assessment support the advancement of teaching and learning (Cao, Jung, \& Lee, 2005; Pinto \& Fernández-Pascual, 2017). Prevost, Vergara, Urban-Lurain, and Campa (2018) found the relationship between the assessment and the teaching and learning, and Pomplun and Omar (2000) found that invariance of a mathematics assessment was supported for factor loadings and intercepts. Assessing student learning support academic progress (Poskitt, 2014), although, students from different countries show the different academic ability of mathematics achievement (Randel, Stevenson, \& Witruk, 2000). Thus, as above work evidenced, assessment support, assessment, as well as invariance of a mathematics assessment influence basic-learning skill. In conclusion, the investigation of the relationship between assessment impact and basic-learning skill, as resulted by literature review, indicates the research and practical importance. Therefore, it is hypothesized that:

$H$ \# 4: The higher assessment impact scores are associated with higher basic-learning skill scores.

\subsubsection{Relationship between prior knowledge, comprehensive learning approach, problem-based teaching, assessment impact, and student's basic-learning skill in mathematics}

Many researchers have done a lot of work to investigate the impact of prior knowledge, comprehensive learning approach, problem-based teaching, and assessment impact on basic-learning skill in mathematics. Approaches to instruction and curriculum design, formative assessment data and feedback to students (Gersten et al., 2009), as well as prior knowledge (Fries, DeCaro, \& Ramirez, 2019) have their impact on students' learning. But, from the other point of view Gruendler (2018) found that none of the previous grades had a significant impact on the students' actual earned grade. A positive effect of pedagogical knowledge on students' learning gains was mediated by the provision of cognitive activation and individual learning support Baumert et al. (2017b), as well as by teachers' mathematical knowledge C. H. Hill et al. (2015). Gearing and Hart (2019) revealed that problem-based lessons increased the students's ability, and Hakyolu and Ogan-Bekiroglu (2016) found a positive relationship between knowledge of students and arguments during a scientific argumentation. On-going professional development 
for teachers are positively associated with student achievement (Fox, 2014; Visser, Juan, \& Hannan, 2019), but Benken, Ramirez, Li, and Wetendorf (2015) reported that merely the number of years of mathematics in high school does not necessarily imply that students are prepared for the level of rigor expected in postsecondary institutions. Hence, it is evidenced that approaches to instruction and curriculum design, formative assessment data, feedback to students, prior knowledge, pedagogical knowledge, individual learning support, teachers' mathematical knowledge, problem-based lessons, on-going professional development for teachers impact student's basic-learning skill in mathematics. Garet et al. (2016) revealed that math content knowledge and instructional practice were generally not correlated with student math achievement, but Lampinen and McClelland (2018) pointed out that pedagogical materials affect learning. Project-based learning instruction, as well as diagnostic assessment information, influenced student achievement in mathematics Han, Capraro, and Capraro (2015); Linsell et al. (2012). Nguyen (2016) found that students with math preference in high school, as well as teaching approach influence the academic outcome (Nguyen, 2016; Santagata \& Yeh, 2014), and teaching techniques influence students' achievement (Kilion, 2016; Rimbey, 2013). Thus, there is evidence that pedagogical materials, project-based learning instruction, diagnostic assessment information, students with math preference in high school, teaching techniques influence student's basic-learning skill in mathematics. In conclusion, the investigation of the relationship between prior mathematics knowledge, comprehensive learning approach, problem-based teaching used by the teacher, assessment impact, and knowledge conceived in mathematics, as confirmed by previous research, is important. Therefore, based on the above previous research it is hypothesized that:

$H$ \# 5: The higher prior knowledge, comprehensive learning approach, problem-based teaching, and higher assessment impact scores predict higher basic-learning skill scores

\section{METHODOLOGY}

\subsection{Method and design}

The quantitative approach was the method used in the research. A quasi-experimental research design was used. Quasi-experimental designs do not include the use of random assignment. Researchers who employ these designs rely instead on other techniques to control, or at least reduce threats to internal validity (Fraenkel, Wallen, \& Hyun, n.d.). Four groups of respondents, two experimental groups, and two control groups of students were involved. Four groups of respondents were non- equivalent. Experimental and control groups of students were selected using existed students' groups in economic and information technology and innovation faculties of the university.

\subsection{Design}

In the quasi-experimental research design, the matching-only design was used in the study. The matching-only design differs from random assignment with matching only in the fact that random assignment is not used. The researcher still matches the subjects in the experimental and control groups on certain variables, but he has no assurance that they are equivalent on others. When several groups are available for a method study and the groups can be randomly assigned to different treatments, this design offers an alternative to random assignment of subjects. After the groups have been randomly assigned to the different treatments, the individuals receiving one treatment are matched with individuals receiving the other treatments (Fraenkel et al., n.d.) . The design is shown in the following Figure, Figure 2. 


$\begin{array}{llll}\text { Treatment groups: } & \text { M } & \text { X } & \text { O } \\ \text { Control groups: } & \text { M } & \text { C } & \text { O }\end{array}$

Figure 2. The matching-only design. Source: Fraenkel et al. (n.d.).

Teaching method was selected to be used as a manipulated variable: traditional vs problem- based teaching, controlling the moderator, mediator and extraneous variables: teaching, curriculum, climate, class management, and technology as a teaching tool. The lecturers of the two experimental groups of students, or the lecturers from economic faculty were trained primarily using four modules with some of the main knowledge and skills in problem-based teaching. Meanwhile, the lectures of the two control groups of students, or lecturers from faculty of information technology and innovation were not trained on this topic. This is the reason why the experimental and control group of respondents were chosen from different faculties.

\subsection{Sample and data collection}

Two experimental and two control groups of freshman and sophomore students as a non-random sample were selected to be investigated in the research. The two experimental groups of students: finance- bank, business- administration (N=135) were selected in the economic faculty of the university. Meanwhile, the two control groups of students: economical informatics, and information technology $(\mathrm{N}=121)$ were selected in information technology and innovation faculty of the university. The four groups of respondents, except the fact that are from different faculties, they were taught the same syllabus of mathematics curriculum. Relating to classification at university, 81 respondents from experimental groups $(60 \%)$ were freshman, and 54 respondents $(40 \%)$ were the sophomore students. Meanwhile, 56 respondents from control groups (46.3\%) were freshman, and 65 respondents $(53.7 \%)$ were the sophomore students. Two experimental groups sample of respondents is composed by 18 females (13.3\%), and 117 (86.7\%) males; meanwhile two control groups sample of respondents is composed by 32 females (26.4\%), and $89(73.6 \%)$ males. Relating to the choice of career, 90 respondents (66.7\%) from experimental groups studied in the first choice, $27(20 \%)$ in the second choice, 9 respondents $(6.7 \%)$ in the third choice, and 9 respondents $(6.7 \%)$ in the fourth choice. Meanwhile, 40 respondents $(33.1 \%)$ from control groups studied in the first choice, $32(26.4 \%)$ in the second choice, 24 respondents (19.8\%) in the third choice, and 25 respondents $(20.7 \%)$ in the fourth choice.

A structured questionnaire was used to gather the primary data from the students in the 2018- 2019 academic year. The questionnaire is based on CEVEAPEU questionnaire- an instrument to assess the learning strategies of university students Gargallo, Suárez-Rodríguez, and Pérez-Pérez (2009), and is modified, piloted and validated by the author. The questionnaire' source is constructed by five dimensions: (1) demographic data of respondents, (2) parents' level of education, (3) grades obtained in the previous academic year, and (4) learning strategies at university (88) items. Meanwhile, the questionnaire used in the research is also compounded by five dimensions, but it has less items (37) than the source.

Alfa Cronbach values of questionnaire scales vary from .83 to .91 confirming a very good value of reliability, as following Table 1.

\subsection{Analysis}

Central tendency values, as well as frequency values, were used to describe the prior mathematics knowledge, comprehensive learning approach, problem-based teaching, 
Table 1. Cronbach's alpha values.

\begin{tabular}{llcl}
\hline NO & Variables & Alpha Cronbach value & Evaluation \\
\hline 1 & Prior knowledge & .89 & Good \\
2 & Comprehensive learning approach & .91 & Excellent \\
3 & Problem-based teaching & .88 & Good \\
4 & Assessment impact & .85 & Good \\
5 & Basic-learning skill & .83 & Good \\
\hline
\end{tabular}

assessment impact, and knowledge conceived in mathematics for both, experimental and control groups. Pearson product-moment correlation coefficient was used to assess the relationship between prior mathematics knowledge, comprehensive learning approach, problem-based teaching, assessment impact, and knowledge conceived in mathematics. Linear multivariate regression was used to assess the ability of one control measure to predict knowledge conceived in mathematics by prior knowledge, comprehensive learning approach, problem-based teaching, and assessment impact. Preliminary assumption testing was conducted to check for normality, linearity, outliers, homogeneity of variance-covariance matrices, and multicollinearity, with no violations noted.

\section{RESULTS}

\subsection{Descriptive statistics}

Frequencies and central tendency values of prior knowledge, comprehensive learning approach, problem-based teaching, assessment impact, and basic-learning skill variables for experimental and control group of respondents are shown below. The statistical tables with frequencies and central tendency values of main variables are shown in the annexes. The more detailed frequencies of main variables according to gender and study program as crosstabs tables are shown in the annexes too.

\subsubsection{Prior knowledge}

Prior knowledge' frequencies indicates that most of the respondents (46.7\%) of the experimental groups and $40.5 \%$ of the control groups passed in the previous academic year; $33.3 \%$ of the experimental groups and $39.7 \%$ of the control groups achieved good results; meanwhile $20 \%$ of the experimental groups and $19.8 \%$ of the control groups achieved high results. Central tendency values for experimental groups $(M=2.733$, SD $=.774)$, as well as for control groups $(\mathrm{M}=4.00, \mathrm{SD}=.897)$, indicate the same tendency for values as measured by frequencies. Hence, there are small differences of prior knowledge (pass: $6.2 \%$; good: $-6.4 \%$; high: $0.2 \%$ ) between the experimental and control groups of students. Therefore, there are small differences of prior knowledge between the experimental and control groups of students.

\subsubsection{Prior knowledge vs current knowledge (pre-post-test)}

Comparing prior knowledge from previous academic year with current knowledge of experimental group has resulted that: (1) $5.93 \%$ more students fail; (2) $2.96 \%$ more students pass, (3) 4.44\% less students achieved good; (4) 4.44\% less students achieved outstanding results in mathematics. Comparing prior knowledge from previous academic year with current knowledge of control group scores has shown that: (1) 9.09 $\%$ more students fail; (2) $6.61 \%$ more students pass, (3) $8.27 \%$ less students achieved good; (4) $7.43 \%$ less students achieved outstanding results. Hence, there is a difference between experimental and control group of students, especially in fail and outstanding 
levels achieved in mathematics.

\subsubsection{Comprehensive learning approach}

Comprehensive learning approach' frequencies indicates that most of the respondents (53.4\%) of experimental groups and $47.1 \%$ of control groups include full information from class reading material, practical, etc. during learning; $13.3 \%$ of the experimental groups and $26.4 \%$ of the control groups include a little; meanwhile $33.3 \%$ of the experimental groups and $26.4 \%$ of the control groups are undecided. Central tendency values for experimental groups $(M=3.46, S D=.808)$, as well as for control groups $(M=2.79, S D$ $=.751$ ) indicate the same tendency for values as measured by frequencies. Therefore, there are small differences of comprehensive learning approach (fully include: 6.3\%; a little include: $-13.1 \%$; undecided: $-6.9 \%$ ) between the experimental and control groups of students.

\subsubsection{Problem-based teaching}

Problem-based teaching' frequencies indicates that most of the respondents (66.7\%) of the experimental groups and $19.8 \%$ of control groups have acquired fully support by lecturers in every lesson during teaching; $6.7 \%$ of the experimental groups, and $60.4 \%$ of the control groups a little support; meanwhile $26.7 \%$ of the experimental groups and $19.8 \%$ of the control groups are undecided. Central tendency values for experimental groups $(M=3.86, \mathrm{SD}=.887)$, as well as for control groups $(\mathrm{M}=3.27$, SD $=.930$ ), indicate the same tendency for values as measured by frequencies. Hence, there are substantial differences of problem-based teaching (fully support: 46.9\%; a little support: $-53.7 \%$; undecided: $6.9 \%$ ) between the students to whom problem-based teaching is used compared to the students to whom the traditional approach is used.

\subsubsection{Assessment impact}

Assessment impact' frequencies indicates that most of the respondents (73.3\%) of experimental groups and $66.9 \%$ of control groups have fully learned from mistakes and study better next time if they don't do well in an exam; $6.7 \%$ of the experimental groups and $6.6 \%$ of the control groups have a little learning; meanwhile $20.0 \%$ of the experimental groups and $26.4 \%$ of the control groups are undecided. Central tendency values for experimental groups $(\mathrm{M}=2.73, \mathrm{SD}=.774)$, as well as for control groups $(\mathrm{M}=$ $3.40, \mathrm{SD}=1.311$ ), indicate the same tendency for values as measured by frequencies. Therefore, there are small differences of assessment impact (fully learned: 6.4\%; a little learned: $0.1 \%$; undecided: $-6.4 \%$ ) between the experimental and control groups of students.

\subsubsection{Basic-learning skill}

Basic-learning skill' frequencies indicates that most of the respondents $(53.4 \%)$ of experimental groups and $53.7 \%$ of control groups are fully able to learn the basic concepts taught in the math course; $6.7 \%$ of the experimental groups and $6.6 \%$ of the control groups are a little able; meanwhile $26.7 \%$ of the experimental groups and $26.4 \%$ of the control groups are undecided. Central tendency values for experimental groups $(\mathrm{M}=$ $4.00, \mathrm{SD}=.897)$, as well as for control groups $(\mathrm{M}=3.80, \mathrm{SD}=.832)$, indicate the same tendency for values as measured by frequencies. Hence, there are small differences of basic-learning skill (fully able: $-0.3 \%$; a little able: $0.1 \%$; undecided: $0.3 \%$ ) between the students to whom problem-based teaching is used compared to the students to whom the traditional approach is used.

\subsection{Inferential statistics}


Table 2. Correlations $\left(r^{2}\right)$ Experimental groups.

\begin{tabular}{lccccc}
\hline & Basic-learning skill & Prior knowledge & $\begin{array}{c}\text { Comprehensive } \\
\text { learning approach }\end{array}$ & $\begin{array}{c}\text { Problem-based } \\
\text { teaching }\end{array}$ & $\begin{array}{c}\text { Assessment } \\
\text { impact }\end{array}$ \\
\hline Basic-learning skill & 1.000 & -.008 & .417 & .319 & .029 \\
$\begin{array}{l}\text { Prior knowledge } \\
\text { Comprehensive learning }\end{array}$ & -.008 & 1.000 & & & \\
$\begin{array}{l}\text { approach } \\
\text { Problem-based teaching }\end{array}$ & .417 & & 1.000 & & \\
Assessment impact & .319 & & & 1.000 & 1.000 \\
\hline
\end{tabular}

Table 3. Correlations $\left(r^{2}\right)$ Controlgroups.

\begin{tabular}{|c|c|c|c|c|c|}
\hline & Basic-learning skill & Prior knowledge & $\begin{array}{l}\text { Comprehensive } \\
\text { learning approach }\end{array}$ & $\begin{array}{l}\text { Problem-based } \\
\text { teaching }\end{array}$ & $\begin{array}{l}\text { Assessment } \\
\text { impact }\end{array}$ \\
\hline Basic-learning skill & 1.000 & .003 & .443 & -.048 & .106 \\
\hline Prior knowledge & .003 & 1.000 & & & \\
\hline $\begin{array}{l}\text { Comprehensive learning } \\
\text { approach }\end{array}$ & .443 & & 1.000 & & \\
\hline Problem-based teaching & -.048 & & & 1.000 & \\
\hline Assessment impact & .106 & & & & 1.000 \\
\hline
\end{tabular}

\subsubsection{Test of hypothesis}

Table 2 and Table 3 shows Pearson correlations outputs of the relationships between variables

$\mathrm{H}$ \# 1: As shown in Table 2 and Table 3, there is a negligible correlation between prior knowledge and basic-learning skill variables, $\mathrm{r}^{2}=-.008, \mathrm{n}=135, \mathrm{p}>.005$ for experimental groups, as well as for control groups, $\mathrm{r}^{2}=.003, \mathrm{n}=121, \mathrm{p}>.005$. Furthermore, there is not a statistically significant relationship between prior knowledge and basic-learning skill by students, thus a random chance could explain the result.

$\mathrm{H}$ \# 2: As shown in Table 2 and Table 3, there is a significant positive correlation between comprehensive learning approach and basic-learning skill variables, $\mathrm{r}^{2}=.417$, $\mathrm{n}=135, \mathrm{p}<.005$ for experimental groups as well as for control groups: $\mathrm{r}^{2}=.443, \mathrm{n}=$ $121, \mathrm{p}<.005$. Hence, high scores of comprehensive learning approach are associated with high scores of knowledge conceived.

$\mathrm{H} \#$ 3: As shown in Table 2 and Table 3 , there is a significant positive correlation between problem-based teaching and basic-learning skill variables, $\mathrm{r}^{2}=.319, \mathrm{n}=135, \mathrm{p}$ $<.005$ for experimental groups, meanwhile there is a low negative correlation between these variables for control groups: $\mathrm{r}^{2}=-.048, \mathrm{n}=121, \mathrm{p}<.005$. Therefore, high scores of problem-based learning teaching' strategies are associated with high scores of knowledge conceived. Meanwhile, high scores of traditional learning problembased teaching are associated with low scores of knowledge conceived.

$\mathrm{H}$ \# 4: As shown inTable 2 and Table 3, there is almost a negligible correlation between assessment impact and basic-learning skill variables, $\mathrm{r}^{2}=.029, \mathrm{n}=135, \mathrm{p}<$ .005 for experimental groups as well as for control groups: $\mathrm{r}^{2}=.106, \mathrm{n}=121, \mathrm{p}<.005$. Hence, it is expected that the scores of assessment impact are not likely to associate with the scores of basic-learning skill.

$\mathrm{H}$ \# 5: As shown in Table 4, the total variance of basic-learning skill levels explained by prior knowledge, problem-based teaching, comprehensive learning approach and assessment impact (the model) is $50.8 \%, \mathrm{~F}(4, .933), \mathrm{p}<.005$ for experimental groups, and $54.4 \%, \mathrm{~F}(4, .799), \mathrm{p}<.005$ for control groups. The model reaches statistical significance (Sig. $=.000$; this means $\mathrm{p}<.0005$ ). The $\mathrm{F}$ value, that is the ratio of the mean 
Table 4. R Square values of the relationships between variables.

\begin{tabular}{|c|c|c|c|c|c|c|c|c|c|c|}
\hline \multicolumn{11}{|c|}{ Model Summary } \\
\hline \multicolumn{11}{|c|}{ Experimental groups ${ }^{b}$} \\
\hline \multirow[b]{2}{*}{ Model } & \multirow[b]{2}{*}{$\mathrm{R}$} & \multirow[b]{2}{*}{$\begin{array}{c}\mathrm{R} \\
\text { Square }\end{array}$} & \multirow[b]{2}{*}{$\begin{array}{c}\text { Adjusted } \\
\text { R } \\
\text { Square }\end{array}$} & \multirow[b]{2}{*}{$\begin{array}{l}\text { Std. Error } \\
\text { of the } \\
\text { Estimate }\end{array}$} & \multicolumn{5}{|c|}{ Change Statistics } & \multirow[b]{2}{*}{$\begin{array}{l}\text { Durbin } \\
\text { Watson }\end{array}$} \\
\hline & & & & & $\begin{array}{c}\text { R } \\
\text { Square } \\
\text { Change }\end{array}$ & $\begin{array}{c}\mathrm{F} \\
\text { Change }\end{array}$ & df1 & df2 & $\begin{array}{l}\text { Sig. F } \\
\text { Change }\end{array}$ & \\
\hline 1 & $.713^{a}$ & .508 & .493 & .93370 & .508 & 33.570 & 4 & 130 & .000 & 1.802 \\
\hline \multicolumn{11}{|c|}{ Control groups ${ }^{b}$} \\
\hline \multirow[b]{2}{*}{ Model } & \multirow[b]{2}{*}{$\mathrm{R}$} & \multirow[b]{2}{*}{$\begin{array}{c}\mathrm{R} \\
\text { Square }\end{array}$} & \multirow[b]{2}{*}{$\begin{array}{c}\text { Adjusted } \\
\text { R } \\
\text { Square }\end{array}$} & \multirow[b]{2}{*}{$\begin{array}{l}\text { Std. Error } \\
\text { of the } \\
\text { Estimate }\end{array}$} & \multicolumn{5}{|c|}{ Change Statistics } & \multirow[b]{2}{*}{$\begin{array}{l}\text { Durbin- } \\
\text { Watson }\end{array}$} \\
\hline & & & & & $\begin{array}{c}\mathrm{R} \\
\text { Square } \\
\text { Change }\end{array}$ & $\begin{array}{c}\mathrm{F} \\
\text { Change }\end{array}$ & df1 & df2 & $\begin{array}{l}\text { Sig. F } \\
\text { Change }\end{array}$ & \\
\hline 1 & $.748^{a}$ & .559 & .544 & .79902 & .559 & 36.786 & 4 & 116 & .000 & 1.768 \\
\hline
\end{tabular}

a. Predictors: (Constant), Assessment impact, Prior knowledge, Problem-based teaching, Comprehensive learning approach

b. Dependent Variable: Basic-learning skill

regression sum of squares- an estimate of population variance that accounts for the degrees of freedom indicates that null hypothesis is false (regression coefficients are different from zero).

Table 5. Beta Standardized Coefficients of the relationships between variables.

\begin{tabular}{|c|c|c|c|c|c|c|c|c|c|c|c|c|}
\hline \multirow{3}{*}{$\begin{array}{l}\text { Model } \\
1\end{array}$} & \multicolumn{7}{|c|}{ Coefficients Experimental Groups } & & & & & \\
\hline & \multicolumn{2}{|c|}{$\begin{array}{l}\text { Unstandardized } \\
\text { Coefficients }\end{array}$} & \multirow{2}{*}{$\frac{\begin{array}{l}\text { Standardized } \\
\text { Coefficients }\end{array}}{\text { Beta }}$} & \multirow{2}{*}{ t } & \multirow[t]{2}{*}{ Sig. } & \multicolumn{2}{|c|}{$\begin{array}{l}95 \% \text { Confidence } \\
\text { Interval for B }\end{array}$} & \multicolumn{3}{|c|}{ Correlations } & \multicolumn{2}{|c|}{$\begin{array}{l}\text { Collinearity } \\
\text { Statistics }\end{array}$} \\
\hline & B & Std.Error & & & & $\begin{array}{l}\text { Lower } \\
\text { Bound }\end{array}$ & $\begin{array}{l}\text { Upper } \\
\text { Bound }\end{array}$ & $\begin{array}{l}\text { Zero- } \\
\text { order }\end{array}$ & Partial & Part & Tolerance & VIF \\
\hline (Constant) & 1.016 & .544 & & 1.869 & .064 & -.060 & 2.092 & & & & & \\
\hline $\begin{array}{l}\text { Prior } \\
\text { Knowledge }\end{array}$ & .261 & .107 & .154 & -2.430 & .006 & -.473 & -.048 & -.093 & -.208 & -.149 & .943 & 1.061 \\
\hline $\begin{array}{l}\text { Comprehensive } \\
\text { learning } \\
\text { approach }\end{array}$ & 1.067 & .162 & .658 & 6.571 & .000 & .746 & 1.389 & .646 & .499 & .404 & .377 & 2.651 \\
\hline $\begin{array}{l}\text { Problem- } \\
\text { based } \\
\text { teaching }\end{array}$ & $\begin{array}{c}- \\
320\end{array}$ & .136 & .217 & 2.351 & .002 & .051 & .590 & .565 & .202 & .145 & .445 & 2.246 \\
\hline $\begin{array}{l}\text { Assessment } \\
\text { impact }\end{array}$ & .460 & .111 & -.315 & -4.153 & .000 & -.680 & -.241 & .171 & -.342 & - & .657 & 1.523 \\
\hline \multicolumn{13}{|c|}{ Coefficients_Control groups ${ }^{\mathrm{a}}$} \\
\hline \multirow[t]{2}{*}{$\begin{array}{l}\text { Model } \\
1\end{array}$} & \multicolumn{2}{|c|}{$\begin{array}{l}\text { Unstandardized } \\
\text { Coefficients }\end{array}$} & \multirow{2}{*}{\multicolumn{2}{|c|}{$\begin{array}{l}\text { Standardized } \\
\text { Coefficients }\end{array}$}} & \multirow[t]{2}{*}{ Sig. } & \multicolumn{2}{|c|}{$\begin{array}{c}95.0 \% \\
\text { Confidence } \\
\text { Interval for B }\end{array}$} & \multicolumn{3}{|c|}{ Correlations } & \multicolumn{2}{|c|}{$\begin{array}{l}\text { Collinearity } \\
\text { Statistics }\end{array}$} \\
\hline & B & Std.Error & & & & $\begin{array}{l}\text { Lower } \\
\text { Bound }\end{array}$ & $\begin{array}{l}\text { Upper } \\
\text { Bound }\end{array}$ & $\begin{array}{l}\text { Zero- } \\
\text { order }\end{array}$ & Partial & Part & Tolerance & VIF \\
\hline (Constant) & $\begin{array}{c}- \\
.150\end{array}$ & .478 & & -.313 & .755 & -1.097 & .798 & & & & & \\
\hline $\begin{array}{l}\text { Prior } \\
\text { Knowledge }\end{array}$ & .181 & .098 & .115 & 1.852 & .006 & -.013 & .375 & .055 & .169 & .114 & .982 & 1.018 \\
\hline
\end{tabular}




\begin{tabular}{|c|c|c|c|c|c|c|c|c|c|c|c|c|}
\hline \multicolumn{13}{|c|}{ Table 5 continued } \\
\hline \multicolumn{13}{|c|}{ Coefficients Experimental Groups } \\
\hline $\begin{array}{l}\text { Comprehensiv } \\
\text { learning } \\
\text { approach }\end{array}$ & .800 & .083 & .629 & 9.640 & .000 & .635 & .964 & .666 & .667 & .594 & .892 & 1.121 \\
\hline $\begin{array}{l}\text { Traditional } \\
\text { approach }\end{array}$ & $\begin{array}{c}- \\
.314\end{array}$ & .062 & -.320 & -5.047 & .000 & -.437 & -.191 & -.221 & -.424 & -.311 & .943 & 1.060 \\
\hline $\begin{array}{l}\text { Assessment } \\
\text { impact }\end{array}$ & .276 & .095 & .194 & 2.909 & .004 & .088 & .464 & .326 & .261 & .179 & .852 & 1.174 \\
\hline
\end{tabular}

aDependent variable: Basic-learning skill

For experimental groups, beta value for prior knowledge is-.154, for comprehensive learning approach, is .658, for problem-based teaching is .217, and for assessment impact is -.315. The largest beta standardized coefficient is .658, which is for comprehensive learning approach.

For control groups, beta value for prior knowledge is.115, for comprehensive learning approach is .629, for the traditional approach is -.320, for assessment impact, is .194. The largest beta standardized coefficient is .629, which is for comprehensive learning approach.

\section{DISCUSSION AND IMPLICATIONS}

According to frequencies as well as the central tendency values, there are small differences of prior knowledge between the experimental and control groups of students. Thus, the students to whom the problem-based-learning approach is used reported higher levels of prior knowledge compared to the students to whom the traditional approach is used. Comparing prior knowledge from previous academic year with current knowledge scores it is found that there is a difference between experimental and control group of students, especially in fail and outstanding levels achieved in mathematics. Therefore, faculties, as well as mathematics departments might pretest prior knowledge of students to strengthen their work to increase their academic success in mathematics.

Frequencies as well as the central tendency values indicate that there are small differences of comprehensive learning approach between the students to whom problembased-learning approach is used compared to the students to whom traditional approach is used. Hence, faculties, as well as mathematics departments might promote the comprehensive learning approach.

Frequencies as well as the central tendency values indicate that there are bigger differences of problem-based teaching between or the students to whom problem-basedlearning approach is used compared to the students to whom traditional approach is used. Hence, faculties, as well as mathematics departments might promote and use more problem-based teaching.

According to frequencies as well as the central tendency values there are small differences of assessment impact between the students to whom problem-based-learning approach is used, compared to the students to whom the traditional approach is used.

Therefore, faculties, as well as mathematics departments might use assessment to increase its impact on students' learning to learn from mistakes and study better next time if they don't do well in an exam.

Frequencies, as well as the central tendency values, indicate that there are small differences of basic-learning skill between the students to whom problem-based-learning approach is used, compared to the students to whom traditional approach is used. Hence, faculties, as well as mathematics departments might support the students to be able to learn the basic concepts taught in the math course. 
Pearson correlation outputs indicate that there is a negligible correlation between prior knowledge and basic-learning skill variables $\left(\mathrm{r}^{2}=-.008\right)$ for experimental groups as well as for control groups $\left(\mathrm{r}^{2}=.003\right)$. Furthermore, there is not a statistically significant relationship between prior knowledge and basic-learning skill by students, thus a random chance could explain the result. The value of correlation indicates that other variables might be important in variance prediction of basic-learning skill scores. So, future researchers may do more work to investigate the influence of other variables on basic-learning skill. The result was not consistent with some previously reported works, who argued that prior knowledge influence basic-learning skill scores (James et al., 2008; Lambić \& Lipkovski, 2012; Lin \& Liou, 2019; Mutodi \& Ngirande, 2014; Reinholz \& Gillingham, 2017; Richardson et al., 2012). Meanwhile other authors (Fernández \& Figueiras, 2014; Flitcroft \& Woods, 2018; H. C. Hill et al., 2004; Hollingsworth \& Knight-McKenna, 2018; Kizito et al., 2016; Remillard, 2005; Schlomer, 2017; Tachie \& Molepo, 2019) revealed the other variables that impact basic-learning skill scores in mathematics, including students' workload, teachers' knowledge, curriculum, and pedagogy. In conclusion, $\mathrm{H} \#$ 1: The higher prior knowledge scores are associated with higher basic-learning skill scores, is been rejected.

Pearson correlation outputs indicate that there is a significant positive correlation between comprehensive learning approach and basic-learning skill variables $\left(\mathrm{r}^{2}=.417\right)$ for the experimental groups as well as for control groups $\left(\mathrm{r}^{2}=.443\right)$. Therefore, high scores of comprehensive learning approach are associated with high scores of basiclearning skill. The value of $\mathrm{r}^{2}$ indicates that other variables might be important in variance prediction of basic-learning skill scores. So, future researchers may do more research to investigate the influence of other variables on basic-learning skill. The result was consistent with some previously reported works, who argued that comprehensive learning approach influence basic-learning skill scores (Alkhateeb, 2003; Gilstrap, 2019; C. H. Hill et al., 2015; Holmes \& Hwang, 2016; Jenkins, 2017; Johnson et al., 2017; Karagiannopoulou \& Christodoulides, 2005; Kogan \& Laursen, 2014; Ma et al., 2016; Rimbey, 2013; Tsouccas \& Meletiou-Mavrotheris, 2019; Wyse \& Soneral, 2018; Yildirim, 2017). In conclusion, $\mathrm{H} \# 2$ : The higher comprehensive learning approach scores are associated with higher basic-learning skill scores, is been supported.

Pearson correlation outputs indicate that there is a significant positive correlation between problem-based teaching and basic-learning skill variables $\left(\mathrm{r}^{2}=.319\right)$ for the experimental groups, meanwhile, there is a low negative correlation between traditional approach and basic-learning skill for the control groups $\left(\mathrm{r}^{2}=-.048\right)$. Hence, high scores of problem-based learning teaching' strategies are associated with high scores of basic-learning skill. Meanwhile, high scores of traditional teaching are associated with low scores of basic-learning skill. The value of correlation indicates that other variables might be important in variance prediction of basic-learning skill scores. So, future researchers may do more work to investigate the influence of other variables on basic-learning skill. The result was consistent with some previously reported works, who argued that problem-based teaching influence basic-learning skill scores (Baele, 2017; Demir, 2018; Derr, 2017; Giles et al., 2016; C. H. Hill et al., 2015; Huntley, 2013; Karagiannopoulou \& Christodoulides, 2005; Lee \& Chen, 2014; Ma et al., 2016; Maciejewski, 2016; Serra et al., 2017; Ysseldyke et al., 2003). The result was not consistent with a few previously reported works, who argued that problembased teaching does not influence basic-learning skill scores (Chung, 2004; Toetenel \& Rienties, 2016; Wilder \& Berry, 2016). In conclusion, H \# 3: The higher problembased teaching scores are associated with higher basic-learning skill scores, is been supported.

Pearson correlation outputs indicate that there is a negligible correlation between assessment impact and basic-learning skill variables $\left(\mathrm{r}^{2}=.029\right)$ for the experimental groups as well as for control groups $\left(r^{2}=.106\right)$. Therefore, it is expected that the scores 
of assessment impact are not associated with thw scores of basic-learning skill. The value of $\mathrm{r}^{2}$ indicates that other variables might be important in variance prediction of basic-learning skill scores. So, future researchers may do more research to investigate the influence of other variables on basic-learning skill. The result was not consistent with some previously reported works, who argued that assessment impact influence basic-learning skill scores (Abushammala, 2019; Brosvic et al., 2006; Chen, 2006; Karagiannopoulou \& Christodoulides, 2005; Kizito et al., 2016; Lee \& Chen, 2014; Lees \& Anderson, 2015; Pinto \& Fernández-Pascual, 2017; Prevost et al., 2018). In conclusion, $\mathrm{H}$ \# 4: The higher assessment impact scores are associated with higher basic-learning skill scores, is been rejected.

Regression outputs indicate that the total variance of basic-learning skill levels explained by prior knowledge, problem-based teaching, comprehensive learning approach and assessment impact (the model) is $50.8 \%$ for the experimental groups and $54.4 \%$ for the control groups. The model reaches statistical significance (Sig. $=.000$ ).

Problem-based teaching beta value in the experimental groups means that $21.7 \%$ of the variance on basic-learning skill is explained by problem-based teaching. Hence, problem- based learning or manipulated variable is making a significant contribution to the prediction of basic-learning skill dependent variable in the experimental groups.

Traditional approach beta value in the control groups is negative and means that $32.0 \%$ of the variance on basic-learning skill dependent variable is explained by the traditional approach. Therefore, traditional teaching independent non- manipulated variable is making a significant but negative contribution to the prediction of the basiclearning skill dependent variable in the control groups.

Meanwhile, beta values for prior knowledge and assessment impact in the experimental groups are negatives and are explained $15.4 \%$ and $31.5 \%$ of the variance on the dependent variable. The largest beta standardized coefficient is .658, which is for comprehensive learning approach. This means that this variable makes the strongest unique contribution to explaining the dependent variable.

Beta value in the control groups for prior knowledge explain $11.5 \%$, and beta value for assessment impact is negative and explain $19.4 \%$ of the variance on the dependent variable. The largest beta standardized coefficient is .629, which is for comprehensive learning approach. This means that this variable makes the strongest unique contribution to explaining the dependent variable.

Therefore, problem- based teaching is making a significant positive contribution, meanwhile, the traditional approach is making a significant but negative contribution to the prediction of basic-learning skill. The result was consistent with some previously reported works, who argued that higher prior knowledge, comprehensive learning approach, problem-based teaching, and higher assessment impact scores predict higher basic-learning skill scores (Baumert et al., 2017a; Fries et al., 2019; Gearing \& Hart, 2019; Gersten et al., 2009; Hakyolu \& Ogan-Bekiroglu, 2016; Han et al., 2015; C. H. Hill et al., 2015; Kilion, 2016; Lampinen \& McClelland, 2018; Linsell et al., 2012; Nguyen, 2016; Rimbey, 2013; Santagata \& Yeh, 2014). In conclusion, H \# 5: The higher prior knowledge, comprehensive learning approach, problem-based teaching, and higher assessment impact scores predict higher basic-learning skill scores, is been supported.

The results of this study supported by other researchers about the basic-learning skill in mathematics have important implications for future research on academic achievements. Such research should investigate various variables and their relation to basic-learning skill. Results of this study about basic-learning skill also have important implications for practice. The important programs or other interventions should be designed to develop and to support students to obtain better results in mathematics. 


\section{CONCLUSIONS}

Several limitations of the study should be acknowledged as part of the conclusion. First, the measurement of prior knowledge, comprehensive learning approach, problem-based teaching, assessment impact, and basic-learning skill variables is made through using of self- reported instrument. Second, the study included four independent variables, since it is known that basic-learning skill is influenced by other variables as well. The prior assumption was that prior knowledge, comprehensive learning approach, problem-based teaching, and assessment impact student's basic-learning skill.

The results showed that there are small differences of prior knowledge between the students to whom the problem-based teaching approach is used compared to the students to whom the traditional approach is used. The study confirmed that there are small differences of comprehensive learning approach and assessment impact between the students to whom the problem-based teaching approach is used compared to the students to whom the traditional approach is used. The results showed that there are substantial differences of problem-based teaching between the students to whom problem-based teaching is used compared to the students to whom the traditional approach is used. The results showed that there are small differences of basic-learning skill between the students to whom problem-based teaching is used compared to the students to whom the traditional approach is used.

It is found that there is a negligible correlation between prior knowledge and basic-learning skill, and there is not a statistically significant relationship between them. It is found that a comprehensive learning approach correlate positively with knowledge conceived, meanwhile, assessment almost does not correlate. Thus, higher scores of learning approach are associated with higher scores of basic-learning skill. It is found that problem-based teaching correlates positively with basic-learning skill, meanwhile traditional approach correlates negatively with basic-learning skill Thus, higher scores of problem-based teaching are associated with high scores of basic-learning skill, meanwhile higher scores of traditional approach are associated with lower scores of basic-learning skill.

The study found that $50 \%$ of the variance of basic-learning skill levels is explained by prior knowledge, problem-based teaching, comprehensive learning approach, and assessment impact. It is found that problem-based teaching explains $21.7 \%$ of the variance of basic-learning skill, prior knowledge $15.4 \%$, comprehensive learning approach $65.8 \%$, and assessment impact $31.5 \%$. The other variance may be explained by hidden or unknown variables. The study confirmed that the comprehensive learning approach makes the strongest unique contribution to explaining basic-learning skill in mathematics. Problem-based teaching is making a significant positive contribution, meanwhile, the traditional approach is making a significant but negative contribution to the prediction of basic-learning skill in mathematics.

\section{A. APPENDIX}

https://zenodo.org/record/4244124\#.X6voxchKiM8

\section{REFERENCES}

Abushammala, M. (2019). The effect of using flipped teaching in project management class for undergraduate students. Fournal of Technology and Science Education, 9(1), 41-41. https://dx.doi.org/10.3926/jotse.539

Al-Balhan, E. M., \& Soliman, M. M. (2019). The Learning Styles Approach to Math Instruction: Improving Math Achievement and Motivation Among Low Achievers in 
Kuwaiti Elementary Schools. Psychology and Education fournal, 56, 1-2. Retrieved from https://www.psychologyandeducation.net/pae/learning-styles-approach-math -instruction-improving-math-achievement-motivation-among-low-achievers-kuwaiti -elementary-schools-dr-eisa-m-al-balhan-dr-mamdouh-m-soliman

Alkhateeb, H. M. (2003). University Students' Approaches to Learning First-Year Mathematics. Psychological Reports, 93(3), 851-854. https://dx.doi.org/10.2466/ pr0.2003.93.3.851

Baele, L. C. (2017). Middle School Engineering Problem Solving Using Traditional vs. E-PBL Module Instruction (Doctoral dissertation, Aurora University). Retrieved from https:// www.proquest.com/docview/2019181353

Barakat, Z. (2005). Effect of Small Groups Learning Modules on Immediate and Delayed Achievement in Mathematics among Second Grade Female Palestinians Students in Tulkarm City. Journal of the Social Sciences, 33(4), 1017-1017.

Baumert, J., Kunter, M., Blum, W., Brunner, M., Voss, T., Jordan, A., ... Tsai, Y. M. (2017a). Teachers' Mathematical Knowledge, Cognitive Activation in the Classroom, and Student Progress, 47, 133-180. https://doi.org/10.3102/0002831209345157

Baumert, J., Kunter, M., Blum, W., Brunner, M., Voss, T., Jordan, A., ... Tsai, M. J. (2017b). Teachers' Mathematical Knowledge, Cognitive Activation in the Classroom, and Student Progress. American Educational Research fournal, 47, 133-180. https://doi.org/ 10.3102/0002831209345157

Benken, B. M., Ramirez, J., Li, X., \& Wetendorf, S. (2015). Developmental Mathematics Success: Impact of Students' Knowledge and Attitudes. Fournal of Developmental Education, 38(2), 14-22. Retrieved from https://files.eric.ed.gov/fulltext/EJ1083365.pdf

Brooks, J. G., \& Brooks, M. G. (1993). Search of Understanding: The Case for Constructivist Classrooms. Alexandria, VA: Association for Supervision and Curriculum Development.

Brosvic, G. M., Dihoff, R. E., Epstein, M. L., \& Cook, M. L. (2006). Feedback Facilitates the Acquisition and Retention of Numerical Fact Series by Elementary School Students with Mathematics Learning Disabilities. The Psychological Record, 56(1), 35-54. https:// dx.doi.org/10.1007/bf03395536

Burns, M. (2005). Looking at How Students Reason. Educational Leadership, 63(3), 13-1784.

Cao, T. H., Jung, J. Y., \& Lee, J. (2005). Assessment in Gifted Education: A Review of the Literature From. Fournal of Advanced Academics, 28(3), 163-203. https://doi.org/10 $.1177 / 1932202 X 17714572$

Chen, P. P. (2006). Relationship between students' self-assessment of their capabilities and their teachers' judgments of students' capabilities in mathematics problem- solving. Psychological Reports, 98(3), 33-2941.

Chung, I. (2004). A comparative assessment of constructivist and traditionalist approaches to establishing mathematical connections in learning multiplication. Education, 125(2), 13-1172.

Cochran-Smith, M., \& Lytle, S. L. (1999). Relationships of Knowledge and Practice: Teacher Learning in Communities. Review of Research in Education, 24, 249-305. https://doi.org/ 10.3102/0091732X024001249

Crawford, I., \& Wang, Z. (2015). The impact of individual factors on the academic attainment of Chinese and UK students in higher education. Studies in Higher Education, 40(5), 902-920. https://dx.doi.org/10.1080/03075079.2013.851182

Creighton, J. E., \& Dewey, J. (1916). Democracy and Education. The Philosophical Review, 25(5), 735-735. Retrieved from https://dx.doi.org/10.2307/2178611 10.2307/2178611

David, L. (2015). Retrieved from https://www.learning-theories.com/constructivism.html

Demir, M. (2018). Effects of Virtual Manipulatives with Different Approaches on Students' Knowledge of Slope. Journal of Interactive Learning Research, 29(1), 25-50.

Derr, K. (2017). Identifying Consistent Variables in a Heterogeneous Data Set: Evaluation of a Web-Based Pre-Course in Mathematics. Electronic fournal of e-Learning, 15(1), 82-93. 
Dewey, J. (1902). The child and the curriculum. Chicago: University of Chicago Press.

Dewey, J. (1934). The Need for a Philosophy of Education. The New Era in Home and School, $15,211-214$.

Duzhin, F., \& Gustafsson, A. (2018). Machine Learning-Based App for Self-Evaluation of Teacher-Specific Instructional Style and Tools. Education Sciences, 8(1), 7-7. https:// dx.doi.org/10.3390/educsci8010007

Edwards, A. R., Sandoval, C., \& McNamara, H. (2015). Designing for Improvement in Professional Development for Community College Developmental Mathematics Faculty. Fournal of Teacher Education, 66(5), 466-481. https://dx.doi.org/10.1177/ 0022487115602313

Evensen, D. H., \& Hmelo-Silver, C. E. (2000). Problem-based learning: A research perspective on learning interactions (C. E., Ed.). Mahwah, NJ: Lawrence Erlbaum.

Fernández, S., \& Figueiras, L. (2014). Horizon Content Knowledge: Shaping MKT for Continuous Mathematical Education. REDIMAT - fournal of Research in Mathematics Education, 3(1), 7-29. http://dx.doi.org/10.4471/redimat.2014.38

Flitcroft, D., \& Woods, K. (2018). What does research tell high school teachers about student motivation for test performance? Pastoral Care in Education. An International fournal of Personal, Social and Emotional Development, 36, 112-125. https://dx.doi.org/10.1080/ 02643944.2018.1453858

Fox, A. M. (2014). Teacher Self-Efficacy, Content and Pedagogical Knowledge, and Their Relationship to Student Achievement in Algebra I (Doctoral dissertation, The College of William and Mary, Virginia). Retrieved from https://eric.ed.gov/?id=ED556950

Fraenkel, J. R., Wallen, N. E., \& Hyun, H. H. (n.d.). How to Design and Evaluate Research in Education. New York: McGrawHill.

Fries, L., DeCaro, M. S., \& Ramirez, G. (2019). The lure of seductive details during lecture learning. Journal of Educational Psychology, 111(4), 736-749. https://dx.doi.org/10.1037/ edu0000301

Garet, M. S., Heppen, J. B., Walters, K., Parkinson, J., Smith, T. M., Song, M., ... Borman, G. D. (2016, September). Focusing on Teachers' Mathematical Knowledge: The Impact of Content-Intensive Professional Development. Retrieved from https://files.eric.ed.gov/ fulltext/ED569154.pdf

Gargallo, B., Suárez-Rodríguez, J. M., \& Pérez-Pérez, C. (2009). The Ceveapeu Questionnaire. An Instrument to assess the Learning Strategies of University Students. RELIEVE. Revista Electrónica de Investigación y Evaluación Educativa, 15(2), 1-25. Retrieved from https://ojs.uv.es/index.php/RELIEVE/article/view/4156

Gearing, N. V., \& Hart, L. C. (2019). The Impact of Adding Written Discourse to Six Year Olds' Mathematics Explanations within a Problem-Based Learning Unit. European fournal of STEM Education, 4(1). https://dx.doi.org/10.20897/ejsteme/3952

Gersten, R., Chard, D. J., Jayanthi, M., Baker, S. K., Morphy, P., \& Flojo, J. (2009). Mathematics Instruction for Students With Learning Disabilities: A Meta-Analysis of Instructional Components. Review of Educational Research, 79(3), 1202-1242. https://dx.doi.org/ 10.3102/0034654309334431

Giles, R. M., Byrd, K. O., \& Bendolph, A. (2016). An investigation of elementary preservice teachers' self-efficacy for teaching mathematics. Teacher Education \& Development, 3(1), 3-3. https://dx.doi.org/10.1080/2331186x.2016.1160523

Gilstrap, C. (2019). The Start of Something New: A Relationship between the AASL Framework for Learners and IB Approaches to Learning. Knowledge Quest, 47(5), 30-35. Retrieved from https://knowledgequest.aasl.org/coddiwomple-with-the-aasl -standards-in-the-may-june-issue/

Gruendler, D. L. (2018). Student Evaluations of Teaching: Perceptions of Faculty Knowledge and Their Relation to Learning (Doctoral dissertation, Pepperdine University). Retrieved from https://www.proquest.com/docview/2130612285

Hakyolu, H., \& Ogan-Bekiroglu, F. (2016). The interplay between Content Knowledge and 
Scientific Argumentation. EURASIA fournal of Mathematics, 12(1), 3005-3033. https:// doi.org/10.12973/eurasia.2016.02319a

Han, S., Capraro, R., \& Capraro, M. M. (2015). How Science, Technology, Engineering, and Mathematics (STEM) Project-Based Learning (PBL) Affects High, Middle, and Low Achievers Differently: The Impact of Student Factors on Achievement. International fournal of Science and Mathematics Education, 13(5), 1089-1113. https://dx.doi.org/ 10.1007/s10763-014-9526-0

Harwell, M., Post, T. R., Cutler, A., Maeda, Y., Anderson, E., Norman, K. W., \& Medhanie, A. (2009). The Preparation of Students From National Science Foundation-Funded and Commercially Developed High School Mathematics Curricula for Their First University Mathematics Course. American Educational Research fournal, 46(1), 203-231. https:// dx.doi.org/10.3102/0002831208323368

Hilby, A. C., Stripling, C. T., \& Stephens, C. A. (2014). Exploring the Disconnect Between Mathematics Ability and Mathematics Efficacy Among Preservice Agricultural Education Teachers. Fournal of Agricultural Education, 55(5), 111-125. https:// dx.doi.org/10.5032/jae.2014.05111

Hill, C. H., Blazar, D., \& Lynch, K. (2015). Resources for Teaching: Examining Personal and Institutional Predictors of High-Quality Instruction. Aera open(4), 1-1. https://doi.org/ $10.1177 / 2332858415617703$

Hill, H. C., Schilling, S. G., \& Ball, D. L. (2004). Developing Measures of Teachers' Mathematics Knowledge for Teaching. The Elementary School fournal, 105(1), 11-30. https://dx.doi.org/10.1086/428763

Hmelo-Silver, C. E. (2004). Problem-Based Learning: What and How Do Students Learn? Educational Psychology Review, 16(3), 235-266. https://dx.doi.org/10.1023/b:edpr $.0000034022 .16470 . \mathrm{f3}$

Hollingsworth, H. L., \& Knight-McKenna, M. (2018). "I am now confident": academic servicelearning as a context for addressing math anxiety in preservice teachers. Fournal of Early Childhood Teacher Education, 39(4), 312-327. https://dx.doi.org/10.1080/10901027 .2018.1514337

Holmes, V. L., \& Hwang, Y. (2016). Exploring the effects of project-based learning in secondary mathematics education. The fournal of Educational Research, 109(5), 449463. https://dx.doi.org/10.1080/00220671.2014.979911

Hourigan, M., \& Leavy, A. M. (2017). Preservice Primary Teachers' Geometric Thinking: Is Pre-Tertiary Mathematics Education Building Sufficiently Strong Foundations? The Teacher Educator, 52, 346-364. https://dx.doi.org/10.1080/08878730.2017.1349226

Hourigan, M., \& O’Donoghue, J. (2007). Mathematical under-preparedness: the influence of the pre-tertiary mathematics experience on students' ability to make a successful transition to tertiary level mathematics courses in Ireland. International fournal of Mathematical Education in Science and Technology, 38(4), 461-476. https://dx.doi.org/ 10.1080/00207390601129279

Howe, R. K., \& Berv, J. (2000). Constructivism in Education. Ninety-ninth Yearbook of the National Society for the study of Education (D. C. Phillips, Ed.). Part I. Chicago: University of Chicago Press.

Huntley, R. (2013). Pre-Service Primary Teachers' Choice of Mathematical Examples: Formative Analysis of Lesson Plan Data. Mathematics Education Research Group of Australasia. Annual Meeting of the Mathematics Education Research Group of Australasia (MERGA) 36th. Retrieved from http://files.eric.ed.gov/fulltext/ED572908.pdf

James, A., Montelle, C., \& Williams, P. (2008). From lessons to lectures: NCEA mathematics results and first-year mathematics performance. International fournal of Mathematical Education in Science and Technology, 39(8), 1037-1050. https://dx.doi.org/10.1080/ 00207390802136552

Jenkins, J. (2017). The Effectiveness of Project-Based Learning on Mathematics Proficiency with African American Students (Unpublished doctoral dissertation). Mercer University. 
Johnson, W. L., Johnson, A. M., \& Johnson, J. W. (2017). Maximizing Student Achievement: Using Student-Centered Learning. Online Submission. Paper presented at the Annual Meeting of the Science Teachers Association of Texas (STAT).

Kajander, \& Lovric, M. (2005). The transition from secondary to tertiary mathematics: McMaster University experience. International fournal of Mathematical Education in Science and Technology, 36(2-3), 149-160.

Karagiannopoulou, E., \& Christodoulides, P. (2005). The impact of Greek University students' perceptions of their learning environment on approaches to studying and academic outcomes. International fournal of Educational Research, 43(6), 329-350. https://dx.doi .org/10.1016/j.ijer.2006.05.002

Kaur, B. (2017). Impact of the Course Teaching and Learning of Mathematics on Preservice Grades 7 and 8 Mathematics Teachers in Singapore. ZDM Mathematics Education, 49, 265-278. https://doi.org/10.1007/s11858-016-0830-8

Kearns, D. M., \& Fuchs, D. (2018). Does Cognitively Focused Instruction Improve the Academic Performance of Low-Achieving Students? . Exceptional Children, 79(3), 263290. https://doi.org/10.1177/001440291307900200

Kelly, C. A. (2002). Creating equitable classroom climates: An investigation of classroom strategies in mathematics and science instruction for developing preservice teachers' use of democratic social values. Child Study fournal, 32(1), 9-4005.

Kilion, J. (2016). When Teachers Learn to Use Technology, Students Benefit. Lessons from Research. Journal of Staff Development, 37(4), 64-67.

King, D., \& Cattlin, J. (2015). The impact of assumed knowledge entry standards on undergraduate mathematics teaching in Australia. International fournal of Mathematical Education in Science and Technology, 46(7), 1032-1045. https://dx.doi.org/ 10.1080/0020739x.2015.1070440

Kizito, R., Munyakazi, J., \& Basuayi, C. (2016). Factors affecting student success in a first-year mathematics course: a South African experience. International fournal of Mathematical Education in Science and Technology, 47(1), 100-119. https://dx.doi.org/10.1080/ 0020739x.2015.1057247

Kogan, M., \& Laursen, S. L. (2014). Assessing Long-Term Effects of Inquiry-Based Learning: A Case Study from College Mathematics. Innovative Higher Education, 39(3), 183-199. https://dx.doi.org/10.1007/s10755-013-9269-9

Kortjass, M. (2019). Reflective self-study for an integrated learning approach to early childhood mathematics teacher education. South African fournal of Childhood Education, 9(1). https://dx.doi.org/10.4102/sajce.v9i1.576

Krain, M. (2016). Putting the Learning in Case Learning? The Effects of Case-Based Approaches on Student Knowledge, Attitudes, and Engagement. Fournal on Excellence in College Teaching, 27(2), 131-153. Retrieved from http://www.celt.muohio.edu/ject/ issue.php? $\mathrm{v}=27 \& \mathrm{n}=2$

Lambić, D., \& Lipkovski, A. (2012). Measuring the Influence of Students' Attitudes on the Process of Acquiring Knowledge in Mathematics. Croatian fournal Educational / Hrvatski Casopis za Odgoj I Obrazovanje, 14(1), 187-205.

Lampinen, A. K., \& McClelland, J. L. (2018). Different presentations of a mathematical concept can support learning in complementary ways. Fournal of Educational Psychology, 110(5), 664-682. https://dx.doi.org/10.1037/edu0000235

Lee, C. Y., \& Chen, M. J. (2014). The Impacts of Virtual Manipulatives and Prior Knowledge on Geometry Learning Performance in Junior High School. Fournal of Educational Computing Research, 50(2), 179-201.

Lees, R., \& Anderson, D. (2015). Reflections on Academics' Assessment Literacy. London Review of Education, 13(3), 42-48. Retrieved from https://core.ac.uk/download/pdf/ 74393968.pdf

Lin, J. J. H., \& Liou, P.-Y. (2019). Assessing the learning achievement of students from different college entrance channels: a linear growth curve modelling approach. 
Assessment \& Evaluation in Higher Education, 44(5), 732-747. Retrieved from https:// dx.doi.org/10.1080/02602938.2018.1532490 10.1080/02602938.2018.1532490

Linsell, C., Tozer, L., Anakin, M., Cox, A., Jones, R., Mcauslan, E., ... Turner, G. (2012). Teaching Algebra Conceptually: Student Achievement. Mathematics Education Research Group of Australasia. Annual Meeting of the Mathematics Education Research Group of Australasia (MERGA) (35th.

Ma, T., Brown, I. A., Kulm, G., Davis, T. J., Lewis, C. W., \& Allen, G. D. (2016). Constructing and Role-Playing Student Avatars in a Simulation of Teaching Algebra for Diverse Learners. Urban Education, 51(5), 534-555. https://doi.org/10.1177/0042085914542658

Maciejewski, W. (2016). Instructors' Perceptions of Their Students' Conceptions: The Case in Undergraduate Mathematics. International fournal of Teaching and Learning in Higher Education, 28(1), 1-8.

McLeskey, J., \& Waldron, N. L. (2004). Three Conceptions of Teacher Learning: Exploring the Relationship Between Knowledge and the Practice of Teaching. Teacher Education and Special Education: The fournal of the Teacher Education Division of the Council for Exceptional Children, 27, 3-14. https://doi.org/10.1177/088840640402700102

Moallem, M., Hung, W., \& Dabbagh, N. (Eds.). (2019). The Wiley Handbook of Problem-Based Learning. New Jersey: John Wiley \& Sons, Inc.

Mutodi, P., \& Ngirande, H. (2014). Perceptions and Interests of Urban High Density Secondary School Students on Applications of Mathematics to Work-related Situations in Zimbabwe. Journal of Social Sciences, 39(2), 191-201. https://dx.doi.org/10.1080/ 09718923.2014 .11893282

Nguyen, T. M. (2016). Learning Approaches, Demographic Factors to Predict Academic Outcomes. International fournal of Educational Management, 30(5), 653-667. http:// dx.doi.org/10.1108/IJEM-06-2014-0085

OECD. (2019). PISA Results in focus. Retrieved from http://www.oecd.org/pisa/pisa-2015 -results-in-focus.pdf

Pinto, M., \& Fernández-Pascual, R. (2017). How a cycle of information literacy assessment and instruction stimulates attitudes and motivations of LIS students: A competencybased case study. Journal of Librarianship and Information Science, 51(2), 370-386. https://dx.doi.org/10.1177/0961000617742447

Pomplun, M., \& Omar, M. H. (2000). Score comparability of a state mathematics assessment across students with and without reading accommodations. Fournal of Applied Psychology, 85(1), 21-29. https://dx.doi.org/10.1037/0021-9010.85.1.21

Poskitt, J. (2014). Transforming professional learning and practice in assessment for learning. The Curriculum fournal, 25(4), 542-566. https://dx.doi.org/10.1080/09585176.2014 .981557

Prevost, L. B., Vergara, C. E., Urban-Lurain, M., \& Campa, H. (2018). Evaluation of a High-Engagement Teaching Program for STEM Graduate Students: Outcomes of the Future Academic Scholars in Teaching (FAST) Fellowship Program. Innovative Higher Education, 43, 41-55. https://dx.doi.org/10.1007/s10755-017-9407-x

Randel, B., Stevenson, H. W., \& Witruk, E. (2000). Attitudes, beliefs, and mathematics achievement of German and Japanese high school students. International fournal of Behavioral Development, 24(2), 190-198. https://dx.doi.org/10.1080/016502500383313

Reinholz, D. L., \& Gillingham, D. (2017). Forms of Formative Assessment: Eliciting and Using Student Thinking. For the Learning of Mathematics, 37(1), 9-11.

Remillard, J. T. (2005). Examining Key Concepts in Research on Teachers' Use of Mathematics Curricula. Review of Educational Research, 75(2), 211-246. https://doi.org/ 10.3102/00346543075002211

Richardson, M., Abraham, C., \& Bond, R. (2012). Psychological correlates of university students' academic performance: A systematic review and meta-analysis. Psychological Bulletin, 138(2), 353-387. https://dx.doi.org/10.1037/a0026838

Rimbey, K. A. (2013). From the Common Core to the Classroom: A Professional Development 
Efficacy Study for the Common Core State Standards for Mathematics (Doctoral dissertation, Arizona State University, Arizona, USA). Retrieved from https:// repository.asu.edu/attachments/110619/content/Rimbey_asu_0010E_12862.pdf

Santagata, R., \& Yeh, C. (2014). Learning to teach mathematics and to analyze teaching effectiveness: evidence from a video- and practice-based approach. Fournal of Mathematics Teacher Education, 17(6), 491-514. https://dx.doi.org/10.1007/s10857-013 -9263-2

Schaub, M., \& Baker, D. P. (1991). Solving the Math Problem: Exploring Mathematics Achievement in Japanese and American Middle Grades. American fournal of Education, 99(4), 623-642. https://dx.doi.org/10.1086/444000

Schlomer, J. K. (2017). Examining the Impact of Mathematical Knowledge for Teaching on Elementary Instructional Coaches' Work (Unpublished doctoral dissertation). Drake University.

Schmidt, H. G. (1983). Problem-based learning: rationale and description. Medical Education, 17(1), 11-16. https://dx.doi.org/10.1111/j.1365-2923.1983.tb01086.x

Schmidt, H. G. (1993). Foundations of problem-based learning: some explanatory notes. Medical Education, 27(5), 422-432. https://dx.doi.org/10.1111/j.1365-2923.1993.tb00296 $\mathrm{x}$

Schmidt, H. G., Molen, H. T. V. D., Wilkel, W. W. R. T., \& Wijnen, W. H. (2009). Constructivist, Problem-Based Learning Does Work: A Meta-Analysis of Curricular Comparisons Involving a Single Medical School. Educational Psychologist, 44(4), 227249. https://dx.doi.org/10.1080/00461520903213592

Schmidt, H. G., Rotgans, J. I., \& Yew, E. J. H. (2019). Cognitive Constructivist Foundations of Problem-Based Learning. In M. Moallen, W. Hung, \& N. Dabbagh (Eds.), The Wiley Handbook of Problem-Based Learning. New Jersey: John Wiley \& Sons, Inc. https:// doi.org/10.1002/9781119173243.ch2

Serra, M.-A. R., Bikfalvi, A., Masó, J. S., Carrasco, F. P., \& Garcia, J. P. (2017). Improving the learning experience of business subjects in engineering studies using automatic spreadsheet correctors. Fournal of Technology and Science Education, 7(2), 203-203. https://dx.doi.org/10.3926/jotse.252

Solbrekke, T. D., \& Helstad, K. (2016). Student formation in higher education: teachers' approaches matter. Teaching in Higher Education, 21(8), 962-977. https://doi.org/10 .1080/13562517.2016.1207624

Steele, M. D., Johnson, K. R., Otten, S., Herbel-Eisenmann, B. A., \& Carver, C. L. (2015). Improving Instructional Leadership Through the Development of Leadership Content Knowledge. Journal of Research on Leadership Education, 10(2), 127-150. https:// dx.doi.org/10.1177/1942775115569353

Tachie, S. A., \& Molepo, J. M. (2019). Exploring Teachers' Meta-Cognitive Skills in Mathematics Classes in Selected Rural Primary Schools in Eastern Cape, South Africa. Africa Education Review, 16(2), 143-161. https://dx.doi.org/10.1080/18146627.2017 .1384700

Toetenel, L., \& Rienties, B. (2016). Analyzing 157 Learning Designs Using Learning Analytic Approaches to Evaluate the Impact of Pedagogical Decision Making. British fournal of Educational Technology, 47(5), 981-992.

Tsouccas, L. F., \& Meletiou-Mavrotheris, M. (2019). Enhancing In-Service Primary Teachers' Technological, Pedagogical and Content Knowledge on Mobile Mathematics Learning. International fournal of Mobile and Blended Learning, 11(3), 1-18. https://dx.doi.org/ 10.4018/ijmbl.2019070101

Visser, M. M., Juan, A. L., \& Hannan, S. M. (2019). Early learning experiences, school entry skills and later mathematics achievement in South Africa. South African fournal of Childhood Education, 9(1). https://dx.doi.org/10.4102/sajce.v9i1.597

Vygotsky, L. S. (1980). Mind in society: The development of higher psychological processes. Harvard university press. 
White, S. K., \& Nitkin, M. (2014). C Creating a Transformational Learning Experience: Immersing Students in an Intensive Interdisciplinary Learning Environment. International fournal for the Scholarship of Teaching and Learning, 8(2). https:// dx.doi.org/10.20429/ijsotl.2014.080203

Wilder, S., \& Berry, L. (2016). Emporium Model: The Key to Content Retention in Secondary Math Courses. Fournal of Educators Online, 13(2), 53-75. https://dx.doi.org/10.9743/ jeo.2016.2.5

Wyse, S. A., \& Soneral, P. A. G. (2018). It's this Class Hard? Defining and Analyzing Academic Rigor from a Learner's Perspective. CBE - Life Sciences Education, 17(4). https://doi.org/10.1187/cbe.17-12-0278

Yildirim, G. (2017). A New Learning Approach: Flipped Classroom and Its Impacts. Acta Didactica Napocensia, 10(2), 31-44. Retrieved from http://files.eric.ed.gov/fulltext/ EJ1156614.pdf

Ysseldyke, J., Spicuzza, R., Kosciolek, S., Teelucksingh, E., Boys, C., \& Lemkuil, A. (2003). Using a Curriculum-Based Instructional Management System to Enhance Math Achievement in Urban Schools. Journal of Education for Students Placed at Risk (JESPAR), 8(2), 247-265. https://dx.doi.org/10.1207/s15327671espr0802_4 